\title{
Effects of a Warm-Core Eddy on Fish Distributions in the Tasman Sea Off East Australia
}

\author{
Stephen B. Brandt \\ Division of Fisheries Research, CSIRO Marine Laboratories, P.O.B. 21, Cronulla, NSW 2230, Australia
}

\begin{abstract}
Distributions of fishes were determined in and near a warm-core eddy off the east coast of Australia from 28 November to 13 December, 1978. Samples were collected with a midwater trawl $(\mathrm{n}=$ 39) in the upper $500 \mathrm{~m}$ of the water column during day and night. $88 \%$ of the 14602 fish caught. belonged to the family Myctophidae. Few fish $(<4 \%$ of total) were caught during day. At night the structure of the fish community within the eddy was recognizably distinct from that in surrounding water masses. Most fish distributions correlated well with thermal structure. Common species were categorized as eddy species $(n=5)$, outside eddy/cold-water species $(n=5)$, warm-water species $(n=$ $1)$, cold-water species $(n=8)$ and widespread species $(n=7)$ based on nocturnal distributions. Eddy species were largely restricted to warm water within the eddy, whilst warm-water species were also abundant near surface outside the eddy. Outside eddy/cold-water species were caught almost exclusively outside the eddy or at the eddy edge. 2 of these species were concentrated in the cold water outside the eddy. For most cold-water species, the extent of the upward vertical migration at night did not appear to penetrate into the warmer surface layers. Widespread species included 4 of the 5 most abundant species caught ( $60 \%$ of total catch) and occurred inside and outside the eddy and at the eddy edge. Individuals of 4 species caught insıde and outside the eddy differed in size, and individuals of 2 species differed in diet. Distributional patterns are discussed in relation to competıtion, predation and thermal ecology of the species.
\end{abstract}

\section{INTRODUCTION}

Warm-core anticyclonic eddies or rings provide good experimental sites for studying oceanic processes since eddies are relatively closed structures, have extensive hydrographic variability over a small geographic space and form uniquely tractable bodies of water that can be revisited in time series (Wiebe, 1976). In the Tasman Sea, warm-core eddies form a major part of the circulation and water mass structure off the southeast coast of Australia (Hamon, 1965; Andrews and ScullyPower, 1976; Nilsson et al., 1977). These eddies apparently form when a meander of the southward flowing East Australian Current breaks off into a closed ring structure (Nilsson and Cresswell, 1981) and are largely analogous to eddies produced by other major western boundary currents such as the Gulf Stream (Parker, 1971; Fuglister, 1972) and the Kuroshio Current (Tomosada, 1978)

Tasman Sea eddies typically have diameters of 200 $300 \mathrm{~km}$ (Andrews and Scully-Power, 1976). The eddies are lens-shaped with isotherms sloping downward from the eddy edge towards the centre. Wintertime cooling produces a deep vertically mixed layer that can extend to $360 \mathrm{~m}$ or more (Tranter et al., $1980 \mathrm{a}_{\text {; }}$ Brandt et al., 1981). Surface currents of $2.0 \mathrm{~m} \mathrm{~s}^{-1}$ have been measured in eddies and satellite tracking of drogued buoys has shown that eddies can move at least $1.5 \times 10^{-2} \mathrm{~m} \mathrm{~s}^{-1}\left(13 \mathrm{~km} \mathrm{~d}^{-1}\right)$ and may exist for 18 months or more (Nilsson and Cresswell, 1981).

Nutrient cycling and phytoplankton productivity also differ between warm-core eddies and surrounding water masses (Scott, 1978; Tranter et al., $1980 a_{\text {; }}$ Jeffrey and Hallegraeff, 1980). The responses of higher trophic levels are not known although many studies in other areas have shown that micronekton distributions often correspond with water mass structure (Hutchins, 1947; Ekman, 1953; Ebeling, 1962; Backus et al., 1969; McGowan, 1971; Foxton, 1972; Jahn and Backus, 1976; Robertson et al., 1979; Fasham and Foxton, 1979; Magnuson et al., in press). In particular, cold-core eddies shed by the Gulf Stream seem to be responsible for much of the large scale patchiness in micronekton distributions in the Western North Atlantic (Wiebe et al., 1976; Wiebe and Boyd, 1978; Ornter et al., 1979).

In this study I sought to determine, in a preliminary 
manner, the effects of a warm-core eddy on fish by comparing biomass, species composition and size structure and diet of selected species among samples collected inside, outside and at the edge of a warmcore eddy. This work forms the first part of a long term program to examine the physics and biology of warmcore eddies and to assess the impact of eddies on oceanic processes in surrounding water masses.

\section{MATERIALS AND METHODS}

\section{Study Area}

A warm-core eddy, named 'Eddy $F$ ', was studied in the Tasman Sea off the southeast coast of Australia from 28 November to 13 December 1978. A detailed history of Eddy F prior to this time can be found in Tranter et al. (1980 b) and references cited therein. Briefly, Eddies E and F were formed by the subdivision of a larger eddy sometime between May and September, 1978. The parent Eddy D apparently originated from a meander of the East Australian Current in February, 1978. During September Eddy F was in a typical winter condition with a uniformly mixed layer $\left(17.5^{\circ}-17.7^{\circ} \mathrm{C}\right)$ extending from the surface to $200 \mathrm{~m}$, high nitrate levels (2.9-3.2 $\mu \mathrm{mol} \mathrm{N} \mathrm{l}^{-3}$ ) and phytoplankton concentrations lower than that of surrounding waters. By November, a warm summer cap $\left(18.0^{\circ}-18.2^{\circ} \mathrm{C}\right)$ of $60-65 \mathrm{~m}$ had formed over the top of the eddy core, nutrient levels had decreased $(0.3-0.8$ $\mu \mathrm{mol} \mathrm{N} \mathrm{I}^{-3}$ ) and near surface phytoplankton concentrations were higher inside the eddy than outside. By December phytoplankton was concentrated at the base of the shallow mixed layer, particularly near the eddy centre and perimeter (Tranter et al., $1980 \mathrm{~b}$ ).

\section{Hydrography}

The trawl sampling scheme was based on thermal structure rather than geographic coordinates and thus necessitated routine mapping of the position and configuration of the eddy. Vertical temperature profiles (to $450 \mathrm{~m}$ ) were measured using expendable bathythermographs (Fig. 1) and temperature at $3 \mathrm{~m}$ was recorded continuously. Salinity to $250 \mathrm{~m}$ was measured using water samples collected with Nansen bottles.

\section{Fish Collections}

Fish were collected with a 308 meshes $\times 800 \mathrm{~mm}$ Engel midwater trawl ( $\mathrm{n}=31$ ) having a $10 \mathrm{~mm}$ stretch mesh liner in the cod end (Table 1). Trawls were towed horizontally at depth for $30 \mathrm{~min}$ at a speed of $1.5 \mathrm{~m} \mathrm{~s}^{-1}$. A Simrad FB Trawl Eye was mounted to the headrope of the trawl and provided a continuous record of trawl depth, temperature and vertical opening of the net. The Engel trawl opened vertically about $12 \mathrm{~m}$ and sampled an estimated $600 \mathrm{~m}^{2}$ at the mouth. Eight additional midwater samples were taken with a Frank and Bryce bottom trawl after the Engel net was ripped. This bottom trawl had a $32 \mathrm{~m}$ footrope, stretch mesh size ranging from $229 \mathrm{~mm}$ at the mouth to $38 \mathrm{~mm}$ at the cod end and a $10 \mathrm{~mm}$ stretch mesh liner in the cod end. When fished in midwater the Frank and Bryce trawl opened $4 \mathrm{~m}$ high. Since biomass catch per unit effort differed significantly at night between the two nets (Table 1), results from the Frank and Bryce trawl are used only as an indicator of species presence in an area.

These non-closing nets probably fished during setting and recovery. No attempt was made to subtract species suspected of being caught higher in the water column although the possibility of contamination is considered in the interpretations of individual species' distributions. Time spent fishing through a $100 \mathrm{~m}$ depth range is estimated to be $8-17 \%$ of total fishing time at depth.

Trawl samples were taken inside the eddy, at the eddy edge and outside the eddy Position with respect to the eddy was determined by temperature at a depth of $250 \mathrm{~m}\left(\mathrm{~T}_{250}\right)$. Boland (1973) and Nilsson (1977) have shown that the fastest surface currents occur at the eddy edge at $\mathrm{T}_{250}=15.0^{\circ} \mathrm{C}$. Therefore, I defined the eddy edge as stations with $\mathrm{T}_{250}=14^{\circ}-16^{\circ} \mathrm{C}$. A $\mathrm{T}_{250}$ less than $14^{\circ} \mathrm{C}$ was considered outside the eddy. A $\mathrm{T}_{250}$ more than $16^{\circ} \mathrm{C}$ was considered inside the eddy (Fig. 1, Table 1). At least 2 trawls were taken near $50 \mathrm{~m}, 150 \mathrm{~m}$ and $250 \mathrm{~m}$ inside and outside the eddy during day and night and near $150 \mathrm{~m}$ and $250 \mathrm{~m}$ at the eddy edge at night. Additionally, 1 deep tow (475 m) was taken at night near the eddy centre. Time of sampling was chosen at random. Mean trawl temperatures ranged from $10.5^{\circ}-19.9^{\circ} \mathrm{C}$.

Fish from each trawl were weighed en masse and preserved in $10 \%$ seawater formalin. Occasionally, subsamples were frozen for stomach analyses. All fish were identified to species if possible and counted. Total length was measured to the nearest mm for the more common species. Systematics follow Greenwood et al. (1966), Baird (1971) and Bigelow et al. (1964). Species of the family Myctophidae were identified using a key to the Australian myctophids developed at the Australian Museum, Sydney (Paxton, unpubl.), Nafpaktitis et al. (1977) and Nafpaktitis (1978). Stomach contents of Scopelopsis multipunctatus ( $n=$ 69) and Ceratoscopelus warmingii ( $n=20$ ) were counted and identified. 
Table 1. Trawl stations and fish catch (biomass and number of myctopid species per trawl). Beginning times and positions given

\begin{tabular}{|c|c|c|c|c|c|c|c|c|c|c|}
\hline Position & & Time & $\begin{array}{l}\text { Date } \\
\text { Dec. }\end{array}$ & $\begin{array}{l}\text { Lat. } \\
\text { S }\end{array}$ & $\begin{array}{c}\text { Long. } \\
W\end{array}$ & $\begin{array}{c}\text { Depth } \\
(\mathrm{m})\end{array}$ & $\begin{array}{c}\mathrm{T} \\
\left({ }^{\circ} \mathrm{C}\right)\end{array}$ & $\begin{array}{l}T_{250} \\
\left({ }^{\circ} \mathrm{C}\right)\end{array}$ & $\begin{array}{c}\text { No.Myc. } \\
\text { species }\end{array}$ & $\begin{array}{c}\text { Biomass } \\
(\mathrm{g})\end{array}$ \\
\hline \multirow[t]{16}{*}{ Inside } & \multirow[t]{8}{*}{ Day } & 1020 & 9 & $36^{\circ} 34^{\prime}$ & $151^{\circ} 27^{\prime}$ & 48 & 18.2 & 17.3 & 0 & 20 \\
\hline & & 1920 & 1 & $36^{\circ} 24^{\prime}$ & $151^{\circ} 24^{\prime}$ & 50 & 18.1 & 16.6 & 0 & 25 \\
\hline & & 1350 & 9 & $36^{\circ} 33^{\prime}$ & $151^{\circ} 27^{\prime}$ & 52 & 18.2 & 17.6 & 0 & 10 \\
\hline & & 1500 & 9 & $36^{\circ} 35^{\prime}$ & $151^{\circ} 26^{\prime}$ & 148 & 17.7 & 17.6 & 0 & 20 \\
\hline & & 1240 & 9 & $36^{\circ} 30^{\prime}$ & $151^{\circ} 26^{\prime}$ & 160 & 17.8 & 17.7 & 0 & 20 \\
\hline & & 0945 & 12 & $36^{\circ} 31^{\prime}$ & $151^{\circ} 05^{\prime}$ & 244 & 16.3 & 16.2 & 2 & $20^{\circ}$ \\
\hline & & 1125 & 9 & $36^{\circ} 31^{\prime}$ & $151^{\circ} 27^{\prime}$ & 260 & 17.7 & 17.7 & 1 & 30 \\
\hline & & 1615 & 9 & $36^{\circ} 32^{\prime}$ & $151^{\circ} 27^{\prime}$ & 260 & 17.5 & 17.5 & 4 & 250 \\
\hline & \multirow[t]{8}{*}{ Night } & 2350 & 1 & $36^{\circ} 29^{\prime}$ & $151^{\circ} 24^{\prime}$ & 32 & 18.3 & 17.4 & 14 & 3010 \\
\hline & & 2050 & 8 & $36^{\circ} 35^{\prime}$ & $151^{\circ} 26^{\prime}$ & 45 & 18.1 & 17.3 & 12 & 610 \\
\hline & & 0120 & 9 & $36^{\circ} 35^{\prime}$ & $151^{\circ} 27^{\prime}$ & 50 & 18.0 & 17.4 & 16 & 2270 \\
\hline & & 2150 & 8 & $36^{\circ} 33^{\prime}$ & $151^{\circ} 27^{\prime}$ & 155 & 17.5 & 17.3 & 16 & 1043 \\
\hline & & 0015 & 9 & $36^{\circ} 30^{\prime}$ & $151^{\circ} 28^{\prime}$ & 158 & 17.4 & 17.4 & 18 & 1820 \\
\hline & & 2305 & 8 & $36^{\circ} 31^{\prime}$ & $151^{\circ} 27^{\prime}$ & 255 & 17.3 & 17.3 & 23 & 1150 \\
\hline & & 0240 & 9 & $36^{\circ} 35^{\prime}$ & $151^{\circ} 27^{\prime}$ & 255 & 17.3 & 17.3 & 20 & 1417 \\
\hline & & 2215 & 1 & $36^{\circ} 26^{\prime}$ & $151^{\circ} 24^{\prime}$ & 475 & 10.5 & 17.0 & 22 & 1010 \\
\hline \multirow[t]{9}{*}{ Edge } & \multirow[t]{2}{*}{ Day } & 1125 & 1 & $36^{\circ} 24^{\prime}$ & $151^{\circ} 01^{\prime}$ & 50 & 18.2 & 14.7 & 0 & 25 \\
\hline & & 1055 & 12 & $36^{\circ} 33^{\prime}$ & $151^{\circ} 03^{\prime}$ & 245 & 15.4 & 15.3 & 2 & $30^{a}$ \\
\hline & \multirow[t]{7}{*}{ Night } & 2115 & 11 & $35^{\circ} 36^{\prime}$ & $151^{\circ} 26^{\prime}$ & 48 & 19.5 & 14.2 & 10 & $10^{d}$ \\
\hline & & 2215 & 11 & $35^{\circ} 34^{\prime}$ & $151^{\circ} 26^{\prime}$ & 152 & 16.6 & 14.2 & 13 & $140^{\mathrm{a}}$ \\
\hline & & 2340 & 3 & $36^{\circ} 16^{\prime}$ & $151^{\circ} 56^{\prime}$ & 165 & 17.0 & 15.9 & 15 & 510 \\
\hline & & 0105 & 10 & $36^{\circ} 33^{\prime}$ & $150^{\circ} 56^{\prime}$ & 245 & 15.8 & 15.7 & 29 & 1388 \\
\hline & & 2330 & 11 & $35^{\circ} 37^{\prime}$ & $151^{\circ} 27^{\prime}$ & 248 & 15.4 & 15.3 & 6 & $50^{a}$ \\
\hline & & 0100 & 12 & $35^{\circ} 44^{\prime}$ & $151^{\circ} 24^{\prime}$ & 250 & 15.3 & 15.3 & 11 & $40^{\mathrm{a}}$ \\
\hline & & 2345 & 9 & $36^{\circ} 30^{\prime}$ & $150^{\circ} 57^{\prime}$ & 260 & 15.6 & 15.7 & 26 & 1090 \\
\hline \multirow[t]{14}{*}{ Outside } & \multirow[t]{8}{*}{ Day } & 1055 & 10 & $36^{\circ} 40^{\prime}$ & $150^{\circ} 30^{\prime}$ & 50 & 19.2 & 11.8 & 0 & 30 \\
\hline & & 1755 & 10 & $36^{\circ} 58^{\prime}$ & $150^{\circ} 40^{\prime}$ & 52 & 19.9 & 12.6 & 0 & 20 \\
\hline & & 1355 & 12 & $36^{\circ} 44^{\prime}$ & $150^{\circ} 58^{\prime}$ & 148 & 14.9 & 13.0 & 0 & $5^{a}$ \\
\hline & & 1330 & 10 & $36^{\circ} 46^{\prime}$ & $150^{\circ} 33^{\prime}$ & 149 & 14.2 & 11.8 & 0 & 50 \\
\hline & & 1505 & 12 & $36^{\circ} 40^{\prime}$ & $151^{\circ} 00^{\prime}$ & 150 & 16.0 & 13.7 & 1 & $20^{a}$ \\
\hline & & 0955 & 10 & $36^{\circ} 37^{\prime}$ & $150^{\circ} 30^{\prime}$ & 152 & 14.1 & 12.0 & 0 & 20 \\
\hline & & 1210 & 10 & $36^{\circ} 42^{\prime}$ & $150^{\circ} 30^{\prime}$ & 245 & 11.9 & 11.8 & 0 & 25 \\
\hline & & 1450 & 10 & $36^{\circ} 50^{\prime}$ & $150^{\circ} 35^{\prime}$ & 252 & 11.8 & 11.8 & 0 & 20 \\
\hline & \multirow[t]{6}{*}{ Night } & 0315 & 3 & $36^{\circ} 04^{\prime}$ & $152^{\circ} 42^{\prime}$ & 52 & 17.5 & 11.3 & 11 & 13450 \\
\hline & & 0150 & 3 & $36^{\circ} 04^{\prime}$ & $152^{\circ} 41^{\prime}$ & 55 & 17.5 & 11.5 & 9 & 4400 \\
\hline & & 0005 & 3 & $36^{\circ} 04^{\prime}$ & $152^{\circ} 51^{\prime}$ & 150 & 13.4 & 12.2 & 21 & 1675 \\
\hline & & 0420 & 3 & $36^{\circ} 04^{\prime}$ & $152^{\circ} 45^{\prime}$ & 152 & 12.8 & 11.3 & 19 & 1650 \\
\hline & & 2130 & 2 & $36^{\circ} 04^{\prime}$ & $152^{\circ} 46^{\prime}$ & 255 & 13.1 & 13.2 & 24 & 1150 \\
\hline & & 2250 & 2 & $36^{\circ} 04^{\prime}$ & $152^{\circ} 50^{\prime}$ & 255 & 12.4 & 12.5 & 23 & 2002 \\
\hline
\end{tabular}

\section{RESULTS}

\section{Eddy Structure}

The thermal structure of Eddy $\mathrm{F}$ at a depth of $250 \mathrm{~m}$ is given in Fig. 1. The eddy was centred at Lat. $36^{\circ} 30^{\prime} \mathrm{S}$, Long. $151^{\circ} 42^{\prime} \mathrm{E}$. Eddy diameter (position of the $15^{\circ} \mathrm{C}$ isotherm) was about $120 \mathrm{~km}$ at $250 \mathrm{~m}$ and decreased to $35 \mathrm{~km}$ at $400 \mathrm{~m}$. Temperature at $250 \mathrm{~m}$ changed up to $8 \mathrm{C}^{\circ}$ over a distance of $90 \mathrm{~km}$. Whether Eddy F was a closed ring during this study is not known because temperature data were not taken at the southern sec- tion of the eddy. Tranter et al. $(1980 \mathrm{c})$, however, showed that the southern edge of Eddy $F$ was closed 2 weeks before this study in late November.

Eddy $F$ apparently moved north-northwesterly during the study (Fig. 1). The $15^{\circ} \mathrm{C}$ isotherm at $250 \mathrm{~m}$ shifted approximately $55 \mathrm{~km}$ northward at an estimated mean rate of $6 \mathrm{~km} \mathrm{~d}^{-1}$. This shift could have resulted from either an active movement of the eddy, or a deepening or tilting of the mixed layer. The latter may have been caused by the passage of a violent storm through the sampling area between 4-7 December. 

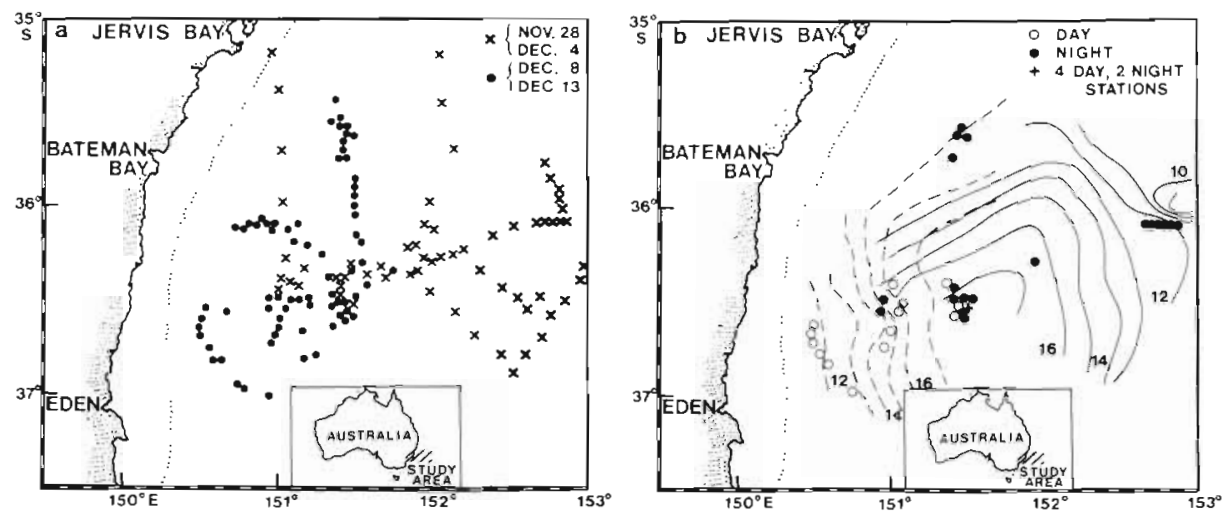

Fig. 1. XBT stations (a); trawl stations (b); temperature at a depth of $250 \mathrm{~m}$ from 28 November to 4 December (solid lines) and 8 to 13 December (dashed lines)

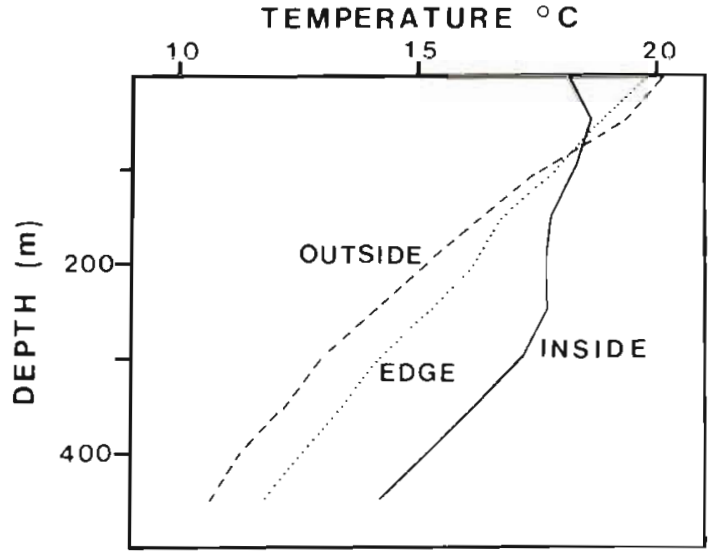

Fig. 2. Thermal profiles inside the eddy (Lat. $36^{\circ} 30^{\prime} \mathrm{S}$, Long. $151^{\circ} 26^{\prime} \mathrm{W}$ ), at the eddy edge (Lat. $35^{\circ} 42^{\prime} \mathrm{S}$, Long. $151^{\circ} 26^{\prime} \mathrm{W}$ ), and outside the eddy (Lat. $35^{\circ} 25^{\prime}$ S, Long. $151^{\circ} 22^{\prime} \mathrm{W}$ )

Tranter et al. (1980 b) compared the T-S relationship inside and outside the eddy in the upper $200 \mathrm{~m}$. Temperatures and salinities in Eddy $F$ were clustered at $17^{\circ}-19^{\circ} \mathrm{C}$ and $35.55-35.65 \% \mathrm{~S}$, respectively. Temperatures and salinities outside the eddy had a much broader range $\left(12^{\circ}-22{ }^{\circ} \mathrm{C}, 35.00-35.70 \%\right.$ S). Near surface temperatures outside the eddy were about $2 \mathrm{C}^{\circ}$ higher than those inside the eddy (Fig. 2). Below $100 \mathrm{~m}$ temperatures outside the eddy were consistently cooler than those inside. Vertical thermal gradients in both regions generally ranged from $1.5^{\circ}-2.5^{\circ} \mathrm{C}$ per $100 \mathrm{~m}$.

A thermal cross-section of the eddy is given in Fig. 3. Vertically, the eddy core was lens-shaped with isotherms deepening from the eddy edge towards the centre. The eddy core $\left(17.4^{\circ}-17.7^{\circ} \mathrm{C}, 35.59 \% \mathrm{~S}\right)$ extended from $50 \mathrm{~m}$ to $290 \mathrm{~m}$ in the eddy centre and thinned towards the eddy edge. The core was overlaid by a warm $\left(18^{\circ}-19^{\circ} \mathrm{C}\right)$ surface layer about $50-100 \mathrm{~m}$ thick that was probably caused by surface warming and the establishment of the seasonal thermocline (Tranter et al., 1980 a). A $2^{\circ} \mathrm{C}$ thermal front and salin-
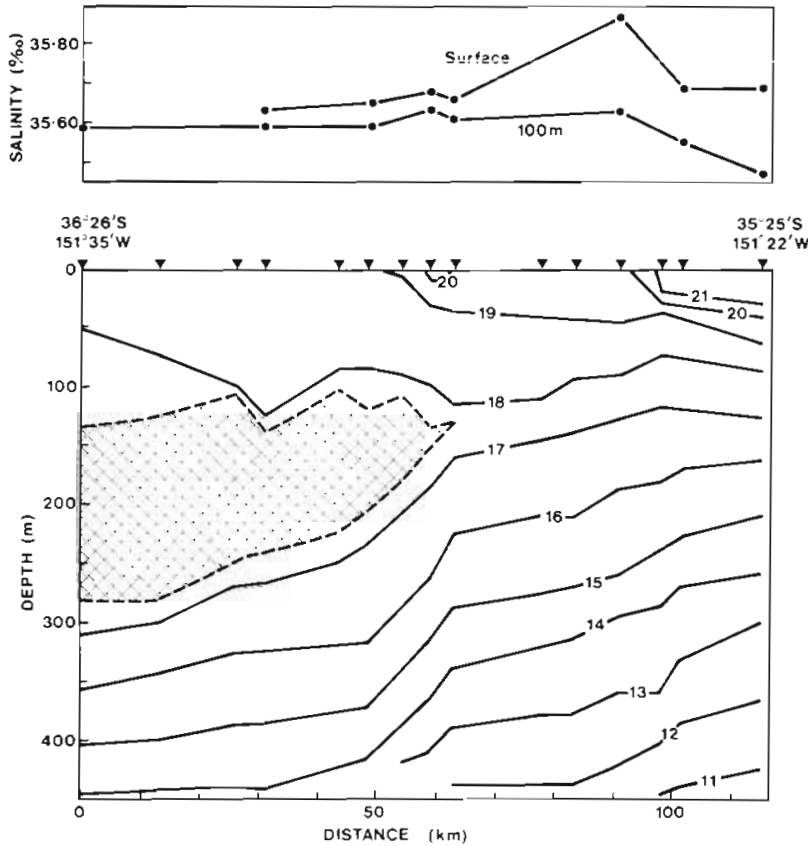

Fig. 3. Thermal structure across the northern section of the eddy (lower panel) during 11 to 12 December Station locations $(\nabla)$ are given. Shaded region represents isothermal $\left(17.4^{\circ}-17.7^{\circ} \mathrm{C}\right)$ eddy core. Salinity at the surface and at $100 \mathrm{~m}$ is given in the upper panel

ity peak were present at the eddy edge on the northern and western boundaries (Fig. 3) Maximum anticyclonic surface currents were $1.2 \mathrm{~m} \mathrm{~s}^{-1}$ at the eddy edge (B. Scott, pers comm.)

\section{Species Composition}

A total of 14602 fish, representing 46 families, over 70 genera and 109 recognized species were caught (Table 2). Myctophids were by far the most abundant group both inside and outside the eddy and rep- 
Table 2. Species list and catch for night (day) samples. Except for myctophids, only species representing more than $0.5 \%$ of total catch are listed

\begin{tabular}{|c|c|c|c|}
\hline Taxa & Number caught & $\%$ of total & $\begin{array}{l}\% \text { occurrence } \\
\text { in trawls }\end{array}$ \\
\hline $\begin{array}{l}\text { BATHYLAGIDAE } \\
\text { Bathylagus argyrogaster Norman, } 1930\end{array}$ & $79(1)$ & 0.55 & $52(6)$ \\
\hline $\begin{array}{c}\text { PHOTICHTHYIDAE } \\
\text { Vinciguerria sp. }\end{array}$ & $145(4)$ & 1.02 & $76(11)$ \\
\hline $\begin{array}{l}\text { STERNOPTYCHIDAE } \\
\text { Argyropelecus hemigymnus Cocco, } 1829\end{array}$ & 73 & 0.50 & 57 \\
\hline $\begin{array}{l}\text { MELANOSTOMIATIDAE } \\
\text { Echiostoma barbatum Lowe, } 1843\end{array}$ & $126(1)$ & 0.87 & $71(6)$ \\
\hline $\begin{array}{l}\text { MYCTOPHIDAE } \\
\text { Electrona risso (Cocco, 1929) }\end{array}$ & $90(15)$ & 0.72 & $24(28)$ \\
\hline Hygophum hygomii (Lütken, 1892) & 896 & 6.14 & 100 \\
\hline Hygophum reinhardtii (Lütken, 1892) & 54 & 0.37 & 52 \\
\hline Hygophum proximum Becker, 1965 & 20 & 0.14 & 29 \\
\hline Benthosema suborbitale (Gilbert, 1913) & 150 & 1.03 & 76 \\
\hline Myctophum phengodes (Lütken, 1892) & 33 & 0.23 & 57 \\
\hline Myctophum brachygnathum (Bleeker, 1856) & 1 & 0.01 & 5 \\
\hline Myctophum orientale (Gilbert, 1913) & 3 & 0.02 & 10 \\
\hline Symbolophorus barnardi (Tânning. 1932) & 60 & 0.41 & 81 \\
\hline Lobianchia dofleini (Zugmayer, 1911) & 339 & 2.32 & 62 \\
\hline Lobianchia gemellarii (Cocco, 1838) & 117 & 0.80 & 29 \\
\hline Diaphus anderseni Tåning, 1932 & $0(1)$ & 0.01 & $0(6)$ \\
\hline Diaphus brachycephalus Tåning, 1928 & 8 & 0.05 & 24 \\
\hline Diaphus mollis Tåning, 1928 & 140 & 0.96 & 62 \\
\hline Diaphus parri Tåning, 1932 & $23(1)$ & 0.16 & $38(6)$ \\
\hline Diaphus meadi Nafpaktitis, 1978 & $1453(196)$ & 11.29 & $86(17)$ \\
\hline Diaphus luetkeni (Brauer, 1904) & 1 & 0.01 & 5 \\
\hline Diaphus termophilus Iåning, 1928 & 711 & 4.87 & 43 \\
\hline Diaphus metopoclampus (Cocco, 1929) & 7 & 0.05 & 19 \\
\hline Diaphus danae Táning, 1932 & 162 & 1.11 & 43 \\
\hline Diaphus fragiljs Táning. 1928 & 92 & 0.63 & 52 \\
\hline Diaphus perspicillatus (Ogilby, 1898) & 12 & 0.08 & 33 \\
\hline Diaphus effulgens (Goode and Bean, 1896) & 5 & 0.03 & 14 \\
\hline Diaphus bertelseni Nafpaktitis, 1966 & $2(2)$ & 0.03 & $10(6)$ \\
\hline Diaphus sp. nov. & 22 & 0.15 & 38 \\
\hline Lampichthys procerus (Brauer, 1904) & 28 & 0.19 & 38 \\
\hline Lampanyctodes hectoris (Günther, 1876) & 79 & 0.54 & 24 \\
\hline Lampanyctus australis Tăning, 1932 & 48 & 0.33 & 38 \\
\hline Lampanyctus alatus Goode and Bean, 1896 & 292 & 2.00 & 76 \\
\hline Lampanyctus pusillus (Johnson, 1890) & 245 & 1.68 & 71 \\
\hline Lampanyctus intricarius Tâning, 1928 & 15 & 0.10 & 48 \\
\hline Lampanyctus lepidolychnus Becker, 1967 & 5 & 0.03 & 14 \\
\hline Lampanyctus festivus Tåning, 1928 & 36 & 0.25 & 52 \\
\hline Lampanyctus ater Tåning, 1928 & 41 & 0.28 & 33 \\
\hline Bolinichthys longipes (Brauer, 1906) & 14 & 0.10 & 29 \\
\hline Bolinichthys nikolayi Bekker, 1977 & 4 & 0.03 & 5 \\
\hline Ceratoscopelus warmingii (Lütken, 1892) & 1194 & 8.18 & 100 \\
\hline Notoscopelus resplendens (Richardson, 1844) & 953 & 6.53 & 95 \\
\hline Scopelopsis multipunctatus Brauer, 1906 & 5286 & 36.20 & 81 \\
\hline $\begin{array}{l}\text { PERCICHTHYIDAE } \\
\text { Howella sherborni (Norman, 1930) }\end{array}$ & $337(1)$ & 2.31 & $57(6)$ \\
\hline CARANGIDAE & & & \\
\hline Trachurus mccullochi Nichols, 1920 & $115(101)$ & 1.48 & $48(39)$ \\
\hline TRICHIURIDAE & & & \\
\hline Lepidopus caudatus (Euphrasen, 1778) & $89(10)$ & 0.68 & $52(33)$ \\
\hline TOTAL & $13605(333)$ & 95.47 & - \\
\hline
\end{tabular}


resented $88 \%$ of total catch. Other taxa representing over $0.5 \%$ of total catch were Percichthyidae (Howella sherborni, $2.3 \%$ ). Carangidae (Trachurus mccullochi, $1.5 \%$ ), Photochthyidae (Vinciguerria sp. 1\%), Melanostomiatidae (Echiostoma barbatum, $0.9 \%$ ), Trichiuridae (Lepidopus caudatus, $0.7 \%$ ), Bathylagidae (Bathylagus argyrogaster, $0.6 \%$ ) and Sternoptychidae (Argyropelecus hemigymnus, 0.5\%). 15 species were represented by only 1 individual and over one-third (47) had fewer than 5 individuals. 26 species occurred in only 1 trawl and 11 occurred in only 2 trawls. Of the species contributing greater than $0.1 \%$ of total catch (i.e. 15 individuals) all were more common at night than during the day, except $T$. mccullochi which occurred in about equal numbers in day and night samples.

Thirty nine species of myctophids were caught (Table 2). Seven species represented $85.7 \%$ of the myctophid catch. Scopelopsis multipunctatus was the most abundant myctophid $(41.1 \%)$ and the most abundant species caught ( $36.2 \%$ of total fish catch). Other common myctophids were Diaphus meadi $(12.8 \%$ of myctophids), Ceratoscopelus warmingii $(9.3 \%)$, Notoscopelus resplendens (7.4\%), Hygophum hygomii $(7.0 \%)$, Diaphus termophilus $(5.5 \%)$ and Lobianchia dofleini $(2.6 \%) .98 \%$ of myctophids were caught at night. C. warmingii and $H$. hygomii were taken in every (21) night sample.

\section{Fish Biomass}

Fish biomass per Engel sample (Table 1) ranged from $0.51-13.45 \mathrm{~kg}$ at night and was significantly larger than the $0.01-0.25 \mathrm{~kg}$ per sample caught during day (Table 1). Catches from the Frank and Bryce trawl at night ranged from $0.01-0.14 \mathrm{~kg}$ and were smaller than catches from the Engel net when corrected for differences in trawl sampling volume. The 2 largest catches were made at a depth of 50 m outside the eddy and consisted primarily of $S$. multipunctatus. Large catches of 2.27 and $3.00 \mathrm{~kg}$ were also taken at 2 of the 3 $50 \mathrm{~m}$ tows inside the eddy. All other night trawls caught $2 \mathrm{~kg}$ of fish or less and no differences were found among depths, temperatures and positions. Catches during the day were small and similar for all samples.

\section{Distribution of Taxa}

Taxa diversity as estimated by number of families per trawl did not differ significantly with position. More families however, occurred at depths of $250 \mathrm{~m}$ or more $($ mean $=18.0$, range $10-21, \mathrm{n}=7)$ and tempera- tures less then $16{ }^{\circ} \mathrm{C}$ (mean $=17.7$, range $13-21, \mathrm{n}=7$ ) than in shallower $($ mean $=10.1$, range $4-14, \mathrm{n}=10$ ) water at night. Fewer families were caught during the day (mean $=5.1$, range $1-9, \mathrm{n}=14$ ) than at night (mean $=13.4$, range $4-21, \mathrm{n}=17)$ for all temperatures and depths.

More species of myctophids were caught at night than during the day (Table 1). At position/depth strata (replicate trawls combined) number of species per trawl ranged from $12-26$ at night and $0-4$ during the day. Within positions more species were caught in deeper water at night. Species counts were largest at $250 \mathrm{~m}$ at the eddy edge and smallest in warm water at $50 \mathrm{~m}$ outside the eddy and at the eddy edge.

\section{Species Distributions}

Species representing more than $0.5 \%$ of total catch were grouped into general distributional patterns based on position with respect to eddy and temperature (Table 3). A Mann-Whitney $U$ test was used to compare night catches between inside and outside the eddy (250 $\mathrm{m}$ stations and shallower) and between warm $\left(\geq 17.0^{\circ} \mathrm{C}\right)$ and cold $(\leq 16.0)$ water at all depths. For position comparisons, if a species was absent from a particular depth in both positions, the depth interval was excluded from the analyses. The following categories were recognized: (1) eddy species; (2) outside eddy/cold-water species; (3) cold-water species; (4) warm-water species; (5) widespread species.

Five common species (Benthosema suborbitale [19-34 mm total length]), Howella sherborni (35-93 mm), Bathylagus argyrogaster, Diaphus fragilis (57-106 mm), and Lobianchia gemellarii (27-52]) were caught primarily inside the eddy (Table 3). Only scattered individuals were found outside the eddy or at the eddy edge. L. gemellarii was not caught at the $50 \mathrm{~m}$ stations. Length frequency distributions of the myctophids $B$. suborbitale, L. gemellarii and $D$. fragilis are given in Fig. 4.

Lepidopus caudatus $(80-422 \mathrm{~mm})$ and Trachurus mccullochi (13-58 mm) were caught primarily outside the eddy at all depths and temperatures and secondarily at $250 \mathrm{~m}$ at the eddy edge (Table 3). During day, $T$. mccullochi also occurred entirely outside the eddy ( $82 \%$ of total catch) and at $250 \mathrm{~m}$ at the eddy edge $(18 \%)$. Capture temperatures ranged from $11.8^{\circ}-19.9^{\circ} \mathrm{C}$ for $T$. mccullochi during the day and $12.8^{\circ}-17.5^{\circ} \mathrm{C}$ for both species at night. T. mccullochi is basically epipelagic and most deep catches were probably from surface contamination. $T$. mccullochi and $L$. caudatus were juveniles and no significant size differences were found among depths and temperatures.

Diaphus dande (14-38 mm) and Lampanyctodes hec- 
Table 3. Ranges of numbers caught in trawl samples at night. Mean depth and temperature (1-3 samples) for each stratum are given. One zero represents absence of species in all samples

\begin{tabular}{|c|c|c|c|c|c|c|c|c|c|}
\hline \multirow{4}{*}{$\begin{array}{l}\text { Depth }(\mathrm{m}) \text { : } \\
\text { Temperature }\left({ }^{\circ} \mathrm{C}\right) \text { : }\end{array}$} & \multicolumn{9}{|c|}{ Position } \\
\hline & \multicolumn{3}{|c|}{ Outside } & \multicolumn{2}{|c|}{ Edge } & \multicolumn{4}{|c|}{ Inside } \\
\hline & 54 & 151 & 255 & 165 & 252 & 42 & 156 & 255 & 475 \\
\hline & 17.5 & 13.1 & 12.8 & 17.0 & 15.7 & 18.1 & 17.4 & 17.3 & 10.5 \\
\hline \multicolumn{10}{|l|}{ Cold-water species } \\
\hline Diaphus termophilus & 0 & $5-104$ & $91-154$ & 0 & $59-222$ & 0 & 0 & $3-13$ & 60 \\
\hline Electrona risso & 0 & $17-52$ & $0-14$ & 0 & $4-4$ & 0 & 0 & 0 & 0 \\
\hline Lobiancha doflejni & 0 & $29-96$ & $57-101$ & 1 & $9-20$ & $0-8$ & $0-2$ & $2-3$ & 0 \\
\hline Lampanyctus australis & 0 & $0-13$ & $4-23$ & 0 & $2-3$ & $0-4$ & 0 & 0 & 10 \\
\hline Chauliodus sloanid & 0 & $0-5$ & $6-9$ & 0 & $6-7$ & $0-1$ & $0-1$ & 0 & 10 \\
\hline Lampanyctus pusillus & 0 & $9-32$ & $39-52$ & 2 & $3-4$ & $0-18$ & $0-8$ & $4-4$ & 53 \\
\hline Argyropelecus hemigymnus & $0-1$ & $2-9$ & $13-24$ & 0 & $4-5$ & $0-1$ & 0 & $4-5$ & 4 \\
\hline Diaphus mollis & 0 & $5-5$ & $23-33$ & 1 & $19-20$ & 0 & $2-4$ & $7-17$ & 2 \\
\hline \multicolumn{10}{|l|}{ Warm-water species } \\
\hline Ceratoscopelus warmingii & $112-237$ & $16-28$ & $15-17$ & 14 & $27-38$ & $18-150$ & $64-73$ & $94-99$ & 41 \\
\hline \multicolumn{10}{|l|}{ Eddy species } \\
\hline Benthosema suborbitale & 0 & $0-3$ & $0-6$ & 1 & $4-5$ & $8-34$ & $2-15$ & $8-8$ & 8 \\
\hline Howella sherborni & 0 & 0 & $2-13$ & 4 & $1-4$ & $0-208$ & $14-21$ & $22-43$ & 4 \\
\hline Bathylagus argyrogaster & $0-2$ & $0-4$ & 0 & 0 & $2-2$ & $0-34$ & $3-4$ & $2-3$ & 5 \\
\hline Diaphus fragilis & $0-1$ & $0-2$ & 0 & 1 & $2-13$ & $0-2$ & $23-31$ & $7-9$ & 0 \\
\hline Lobianchia gemellarii & 0 & $2-3$ & 0 & 0 & 0 & 0 & $35-45$ & $15-17$ & 0 \\
\hline \multicolumn{10}{|l|}{ Outside eddy/cold-water species } \\
\hline Lepidopus caudatus & $2-30$ & $15-23$ & $5-6$ & 0 & $1-3$ & 0 & 0 & $1-1$ & 2 \\
\hline Trachurus mccullochi & $4-13$ & $8-15$ & $12-22$ & 0 & $14-20$ & 0 & $0-1$ & 0 & 0 \\
\hline Scopelopsis multipunctatus $(>70 \mathrm{~mm})$ & $731-2381$ & $53-95$ & $53-94$ & 18 & $8-21$ & $0-5$ & 0 & $0-3$ & 11 \\
\hline Lampanyctodes hectoris & 0 & $1-8$ & $17-34$ & 0 & 0 & 0 & 0 & 0 & 0 \\
\hline Diaphus danae & $0-1$ & $34-35$ & $19-49$ & 0 & $0-1$ & 0 & 0 & 0 & 0 \\
\hline \multicolumn{10}{|l|}{ Widespread species } \\
\hline Scopelopsis multipunctatus $(<70 \mathrm{~mm})$ & $7-34$ & $125-657$ & $21-34$ & 13 & $4-9$ & $84-416$ & $38-58$ & $36-36$ & 15 \\
\hline Diaphus meadi & $0-1$ & $53-165$ & $28-32$ & 8 & $55-206$ & $6-13$ & $154-365$ & $117-189$ & 28 \\
\hline Notoscopelus resplendens & $25-37$ & $3-24$ & $20-44$ & 6 & $28-68$ & $63-383$ & $13-26$ & $18-21$ & 31 \\
\hline Hygophum hygomii & $16-18$ & $28-34$ & $15-55$ & 29 & $19-46$ & $2-184$ & $25-61$ & $62-90$ & 14 \\
\hline Lampanyctus alatus & 0 & $2-9$ & $19-25$ & 8 & $6-7$ & $0-97$ & $19-20$ & $18-25$ & 25 \\
\hline Vinciguerria sp. & 0 & $3-13$ & $8-8$ & 1 & $11-13$ & $0-40$ & $3-8$ & $3-7$ & 10 \\
\hline Echiostoma barbatum & $1-2$ & $1-2$ & $3-5$ & 0 & $0-5$ & $3-41$ & $0-7$ & $1-12$ & 5 \\
\hline
\end{tabular}

toris (34-45 mm) were restricted almost entirely to the cooler water $\left(12.4^{\circ}-13.4^{\circ} \mathrm{C}\right)$ at $150 \mathrm{~m}$ and $250 \mathrm{~m}$ outside the eddy. Length frequency distributions are given in Fig. 4.

Eight species - Diaphus termophilus, Electrona risso (17-39 mm), Lobianchia dofleini (14-48 mm), Lampanyctus australis (19-118 mm), Chauliodus sloani $(64-220 \mathrm{~mm})$, Lampanyctus pusillus $(13-46 \mathrm{~mm})$, Argyropelecus hemigymnus, and Diaphus mollis (20-45 mm) - were caught mainly at temperatures less than $16{ }^{\circ} \mathrm{C}$ at night (Table 3 ). Cold-water species were most abundant at $150 \mathrm{~m}$ and $250 \mathrm{~m}$ outside the eddy, at $250 \mathrm{~m}$ at the eddy edge and occasionally at $475 \mathrm{~m}$ $\left(10.5^{\circ} \mathrm{C}\right)$ inside the eddy. Depth of the mixed layer seemed to determine the shaliowest occurrence for most of these species, particularly $D$. termophilus, $E$. risso, L. australis and C. sloani. Cold-water species (e.g. D. dofleini, D. danae and L. pusillus) had thermal distributions quite distinct from warm-water species (e.g. L. gemellarii and D. fragilis) caught in the eddy (Fig. 5). No significant differences were found in size distribution of $L$. dofleini, $L$. pusillus, $E$. risso and $L$. australis among depths, temperatures or positions (Fig. 4). Mean size of $D$. termophilus at $250 \mathrm{~m}$ was larger at cooler temperatures (Fig. 6). Larger individuals $(50-75 \mathrm{~mm})$ were caught mainly at temperatures less than $14{ }^{\circ} \mathrm{C}$; only small fish were caught in warmer water. Catches of small $D$. termophilus in the cooler water may have occurred as the trawl sampled warmer upper layers during setting and retrieval.

Diaphus mollis caught outside the eddy were larger than those caught inside the eddy ( $\mathrm{p}<0.5$, Median test) for all samples combined or between equivalent depths (Fig. 7). Fish at the edge of the eddy were 


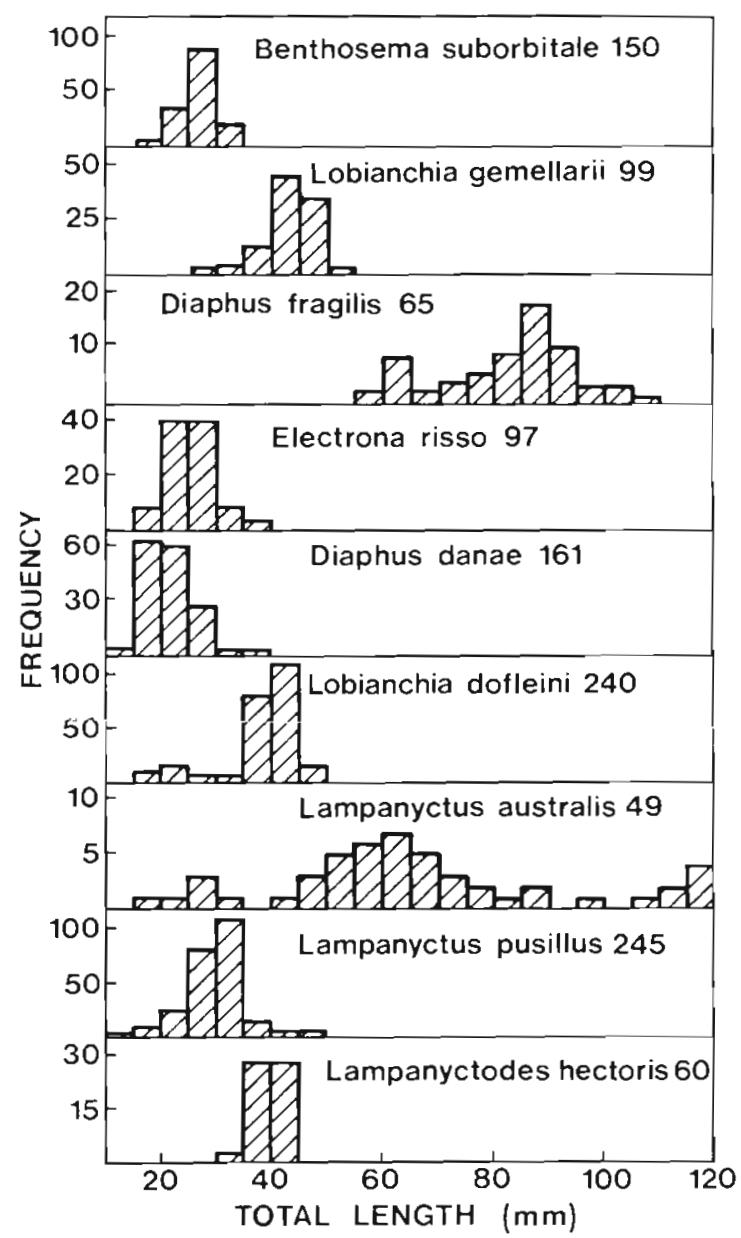

Fig. 4. Frequency distributions of total length of nine species of myctophids. Total number measured follows species name

intermediate in size. These size differences were small and were more likely due to growth rather than age class differences. Within any position, D. mollis were more common in deeper water.

Ceratoscopelus warmingii $(44-109 \mathrm{~mm})$ was the third most abundant species and was caught in all trawl hauls. This species was most common in warm water (Table 3). Largest catches were made inside the eddy and at the warm $50 \mathrm{~m}$ sample outside the eddy Catches at lower temperatures at $150 \mathrm{~m}$ and $250 \mathrm{~m}$ outside the eddy represent $7-25 \%$ of the catches at $50 \mathrm{~m}$ and may be due to trawl contamination. $C$. Warmingii inside the eddy were larger than those outside the eddy ( $p<0.5$. Median Test) for all samples combined or between equivalent depths (Fig. 7). Edge samples were intermediate in size.

A preliminary examination of stomach contents of Ceratoscopelus warmingif showed that individuals caught outside the eddy contained a large number of salps (mainly Thalia democratica), whereas no salps were found in stomachs of fish caught inside the eddy

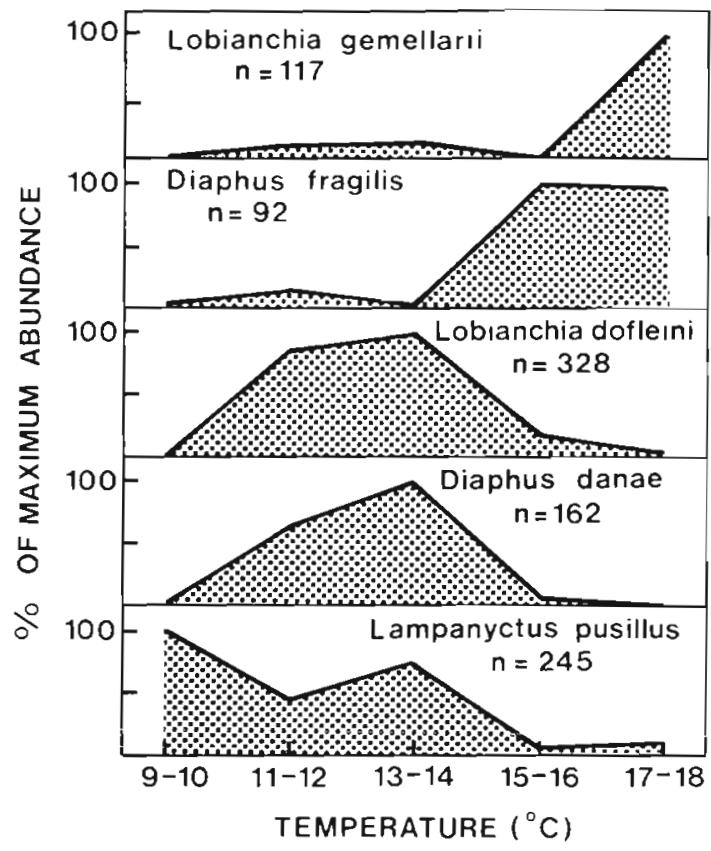

Fig. 5. Abundance of selected species of myctophids at different temperatures. Total number of individuals (n) caught is given. Catches are standardized to per cent of maximum abundance based on mean catch at each $2{ }^{\circ} \mathrm{C}$ for night Engel samples only

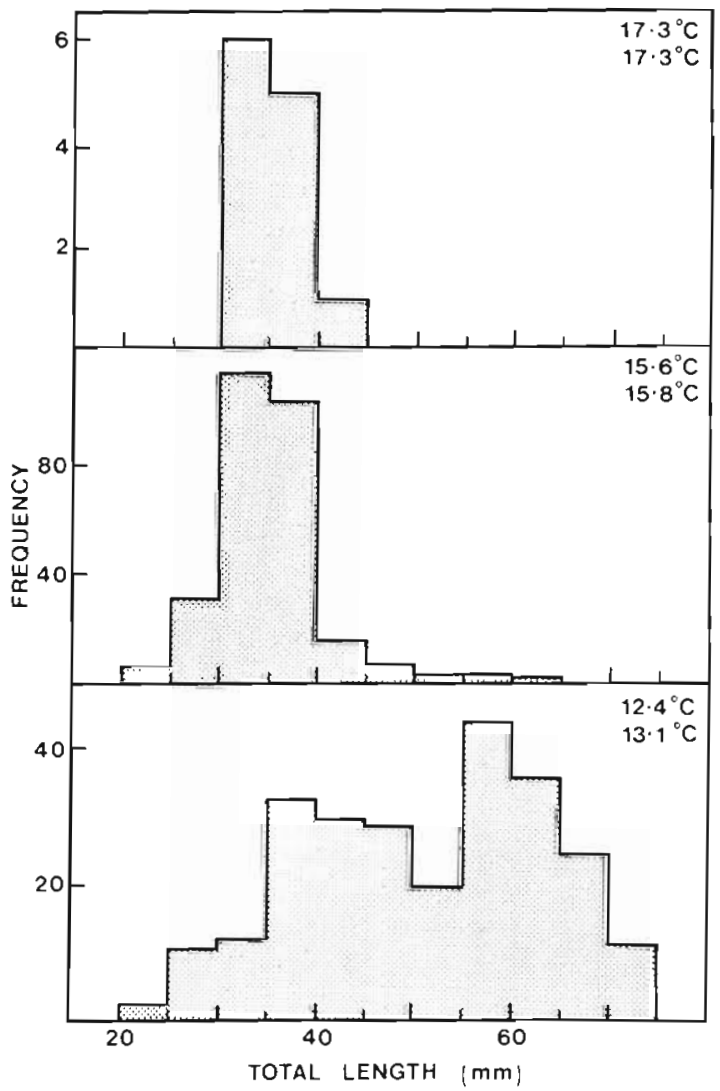

Fig. 6. Diaphus termophilus Frequency distributions of total length at different temperatures at $250 \mathrm{~m}$. Each frame represents the combined catch from two trawl samples 


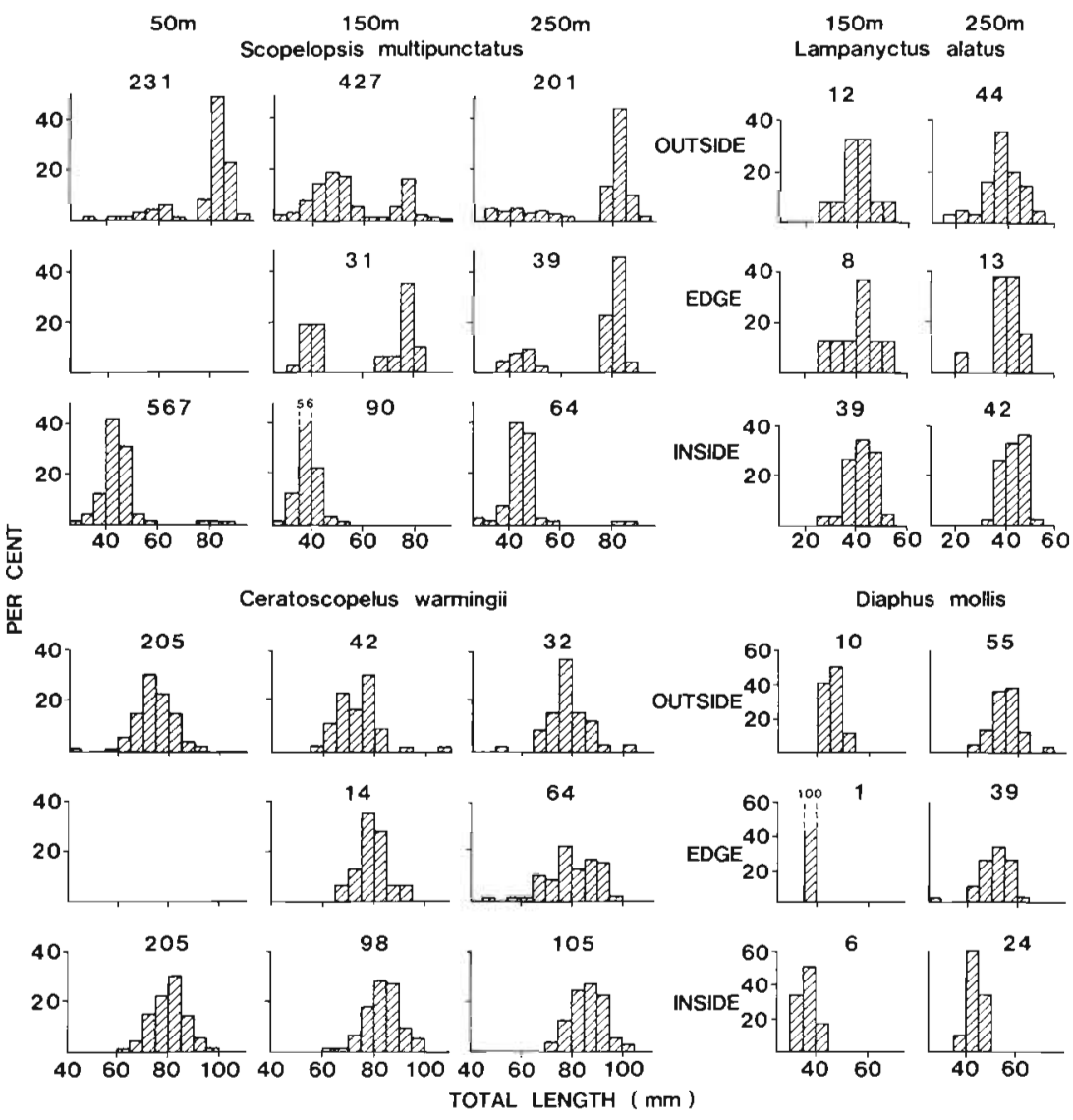

Fig. 7. Comparison of frequency distributions of total length of four species of myctophids among depths and positions (replicate samples combined). Data represent per cent of total measured, which is given

(Table 4). Fish from both regions ate copepods, amphipods, euphausids, and occasionally larval molluscs, ostracods, polychaetes and siphonophores.

Seven common species - Scopelopsis multipunctatus (25-95 mm), Diaphus meadi (20-56 mm), Notoscopelus resplendens (21-115 mm), Hygophum hygomii (23-75 $\mathrm{mm})$, Lampanctus alatus (16-58 mm), Vinciguerria sp. and Echiostoma barbatum - occurred inside the eddy, at the eddy edge and outside the eddy (Table 3 ). These widespread fishes include 4 of the 5 most abundant myctophids.

Diaphus meadi, Notoscopelus resplendens, Hygophum hygomii, Vinciguerria sp. and Echiostoma barbatum did not differ in size distribution among temperatures, depths or positions. Lampanctus alatus were larger inside the eddy than outside the eddy for all samples combined and for the $250 \mathrm{~m}$ depths (Fig. 7). Edge samples were intermediate in size. Size differences were small.

The myctophid Scopelopsis multipunctatus was the most abundant species and accounted for over one third of all fish. This species occurred inside, outside and at the edge of the eddy but a distinct difference was noted in the distribution of size classes. S. multipunctatus caught outside the eddy were larger than those caught inside ( $p<0.5$, Median Test) for all samples combined and between equivalent depths (Fig. 7). Large S. multipunctatus (70-95 mm) were caught almost exclusively outside the eddy or at the eddy edge. Although this group has been statistically placed in the outside eddy/cold-water category (Table 3) it is believed that these fish were concentrated in the shallower warm-water outside the eddy. Catches at $150 \mathrm{~m}$ and $250 \mathrm{~m}$ in the cooler water outside the eddy represent only $2.2-13.0 \%$ of the catches at $50 \mathrm{~m}$ and may have been caught during setting and retrieval of the trawl. Small S. multipunctatus $(25-70 \mathrm{~mm})$ had a widespread distribution (Table 3 ) with largest catches at $50 \mathrm{~m}$ inside the eddy and $150 \mathrm{~m}$ outside the eddy. Within this smaller size range, individuals were larger outside the eddy than inside the eddy (Fig. 7).

Stomach contents of large and small Scopelopsis multipunctatus were compared at different depths and temperatures (Table 4). All stomachs contained copepods, amphipods and euphausiids, and occasionally larval molluscs, ostracods, pollychaetes and 
Table 4. Stomach contents of Scopelopsis multipunctatus and Ceratoscopelus warmingii caught inside and outside the eddy Values represent mean (standard deviation) number of items per stomach

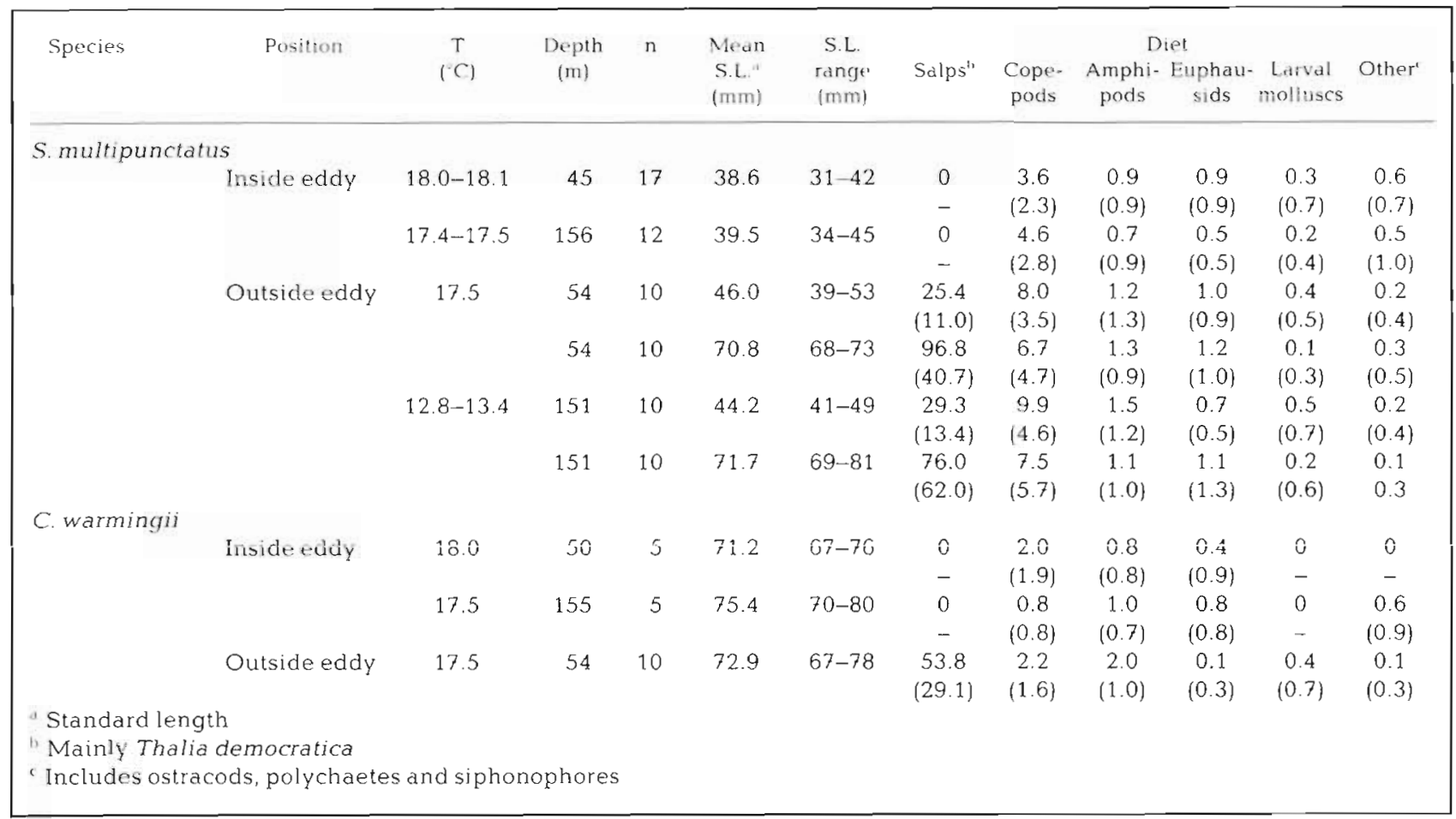

siphonophores. The dominant prey of large and small S. multipunctatus caught at cold and warm water outside the eddy was salps (mainly Thalia democratica). Salps were not found in the stomachs of fish caught inside the eddy.

Some of the less common species also showed distributional trends. Argyropelecus aculeatus were caught primarily at $250 \mathrm{~m}$ (42 individuals out of 45), and were present in all regions. The myctophid Lampichthys procerus was uncommon (only 28 individuals), although it occurred in 6 out of 7 cold water $\left(<16^{\circ} \mathrm{C}\right)$ samples and 26 individuals were taken in cold water (2-11 ind. to $\left.{ }^{-1}\right)$. Similarly, 38 out of 41 Lampancytus ater were caught at temperatures less than $16^{\circ} \mathrm{C}$ and this species occurred in 6 out of 7 cold water samples (2-13 ind. tow ${ }^{-1}$ ). Myctophum phengodes was restricted to temperatures greater than $15^{\circ} \mathrm{C}$, occurring in 10 out of 12 such tows (1-10 ind. to $\left.w^{-1}\right)$. Catches of other species were too small for analyses.

\section{Community Structure}

The community structure at each position (inside eddy, eddy edge and outside eddy) was defined as those species contributing $1 \%$ or more by number to the total catch at that position (Table 5).
Community structure within the eddy was recognizably distinct from that outside the eddy. Five species (Scopelopsis multipunctatus, Diaphus meadi, Ceratoscopelus warmingii, Hygophum hygomii and Notoscopelus resplendens) were common in all regions. No other overlap in dominant species was observed between inside and outside the eddy. Seven species were common only outside the eddy or at the eddy edge. Eight species were common only inside the eddy or at the eddy edge. The edge community was largely intermediate in character with 3 species shared with the inside community only, 3 species shared with the outside community only, and 4 species important only at the edge. Fewer edge samples were taken than in other regions.

\section{DISCUSSION}

\section{Individual Species Distribution and Zoogeography}

Many zoogeographic studies have linked the distribution of mesopelagic fishes (primarily myctophids) and other fauna to specific water masses (Ebeling, 1962; Backus et al., 1969, 1970, 1977; Nafpaktitis and Nafpaktitis, 1969; McGowan, 1974; Backus and Craddock, 1977; Nafpaktitis, 1978). Most work has relied on samples scattered over wide geographic ranges. The 
Table 5. Species composition ( $>1.0 \%$ of total number of i rdividuals at each position) of communities outside, inside and at the edge of the eddy. Values represent percent contribution of each species to each position

\begin{tabular}{|lccc|}
\hline \multicolumn{3}{|c}{ Species } & \multicolumn{3}{c|}{ Per cent of total } \\
& $\begin{array}{c}\text { Outside } \\
\text { eddy }\end{array}$ & $\begin{array}{c}\text { Eddy } \\
\text { edge }\end{array}$ & $\begin{array}{c}\text { Inside } \\
\text { eddy }\end{array}$ \\
\hline Scopelopsis multipunctatus & 60.0 & 5.6 & 18.1 \\
Ceratoscopelus warmingii & 6.0 & 6.1 & 12.7 \\
Diaphus meadi & 3.9 & 20.6 & 17.1 \\
Hygophum hygomii & 2.3 & 7.2 & 11.7 \\
Notoscopelus resplendens & 2.1 & 7.8 & 12.7 \\
Diaphus danae & 1.9 & & \\
Lampanyctus pusillus & 1.9 & & \\
Electrona risso & 1.1 & & \\
Lepidopus caudatus & 1.1 & & \\
Diaphus termophilus & 5.0 & 21.6 & \\
Lobianchia dofleini & 4.0 & 2.3 & \\
Trachurus mccullochi & 1.0 & 2.6 & \\
Diaphus mollis & & 3.1 & \\
Lampanyctus ater & & 1.3 & \\
Argyropelecus aculeatus & & 1.2 & \\
Chauliodus sloani & & 1.0 & \\
Lampanyctus alatus & & 1.6 & 3.7 \\
Diaphus fragilis & & 1.2 & 1.4 \\
Vinciguerria sp. & & 1.9 & 1.3 \\
Howella sherborni & & & 6.2 \\
Lobianchia gemellarii & & & 2.2 \\
Echistoma barbatum & & & 2.0 \\
Benthosema suborbitale & & & 1.9 \\
Bathylagus argyrogaster & & & 1.3 \\
Total number of individuals & 7145 & 1304 & 4994 \\
& & & \\
\hline
\end{tabular}

present study differs because samples were taken in different hydrographic conditions over a small geographic space. The data show that fish distributions corresponded to water masses and the community structure of dominant fishes within a warm-core eddy at night was recognizably distinct from that outside the eddy. The eddy edge was largely a transition zone. A small increase in myctophid diversity was evident at $250 \mathrm{~m}$ at the eddy edge but other ecotone 'edge effects' such as increased diversity or biomass (Odum, 1971; Terborgh, 1971) were not evident.

The associations of particular species with the water masses near Eddy $F$ were similar to those shown from larger scale zoogeographic studies. For example, Backus et al. (1977) classify Benthosema suborbitale and Lobianchia gemellarii as tropical-subtropical species and Diaphus fragilis as a tropical species in the Atlantic Ocean. These species are also considered tropical or subtropical in the Pacific and Indian Oceans (Rass, 1960; Nafpaktitis and Nafpaktitis, 1969; Wisner, 1976; Nafpaktitis, 1978). These eddy species were caught mainly in warm water and probably originated from tropical-subtropical water to the north (Nilsson and Cresswell, in press). The warm-water Ceratoscopelus warmingii also has a tropical-subtropical distribution in the Atlantic (Backus et al., 1977).

Similarly, cold water species have more temperature zoogeographic distributions. Backus et al. (1977) classify Lampanyctus pusillus and Lobianchia dofleini as temperate-semisubtropical species in the Atlantic Ocean. Electrona risso and L. australis are included in Becker's (1964) temperate-cold water complex and $L$. australis occurs primarily between Lat. $31^{\circ} \mathrm{S}$ and Lat. $44^{\circ} \mathrm{S}$ in the Indian Ocean (Nafpaktitis and Nafpaktitis, 1969).

Widespread species have distributions in the Atlantic Ocean (Backus et al., 1977) ranging from tropical (Lampanyctus alatus) to tropical-subtropical, (Notoscopelus resplendens) to temperate-semisubtropical (Hygophum hygomii). $N$ resplendens has a tropicalsubtropical distribution in all oceans (Nafpaktitis, 1975). The widespread Scopelopsis multipunctatus taken both in and near Eddy $F$ has a circumglobal distribution restricted to the southern oceans (Wisner, 1976). This species is generally regarded as a warmwater species. Wisner (1976) records S. multipunctatus only between $15^{\circ}$ and $25^{\circ} \mathrm{S}$ in the Pacific Ocean and Nafpaktitis and Nafpaktitis (1969) record it from $23^{\circ}$ to $29^{\circ} \mathrm{S}$ in the Indian Ocean. S. multipunctatus was not found among the essentially temperate assemblages by Robertson et al. (1979).

Two exceptions to the zoogeographic literature exist. The cold water species Diaphus mollis and D. termophilus are considered to be tropical-subtropical and tropical species, respectively (Wisner, 1976; Backus et al., 1977). This may point out a possible source of variability of general species classification based on large scale geographic distributions without consideration of the local (i.e. at the trawl) hydrographic conditions. Indeed, this study found cold water (temperatesemisubtropical) and warm water (tropical) species within a geographic space of about $100 \mathrm{~km}$. For example, the closely related species Lobianchia dofleini and L. gemellarii are considered to be a temperate-subtropical species and a tropical-subtropical species respectively in the Atlantic (Backus et al., 1977). Nafpaktitis (1978) reported that, in the Indian Ocean, the northernmost limit of $L$. dofleini coincides with the southernmost limit of $L$. gemellarii. In the present study both species were abundant, however, $L$. dofleini was caught primarily in colder waters $198 \%$ of total at $<16^{\circ} \mathrm{C}$ ) and L. gemellarii occurred in warm water $\left(96 \%\right.$ of total at $>17^{\circ} \mathrm{C}$ ). These data indicate that the 2 species may be separated by temperature (Fig. 5).

It is not known how fish are distributed during day because of small catches. During day most of the common fishes (Lobianchia dofleini, L. gemellarii, Ceratoscopelus warmingii, Lampanyctus alatus, $L$. pusillus, Hygophum hygomii, Notoscopelus resplen- 
dens, Diaphus fragilis and Benthosema suborbitale) migrate to depths of $400-1000 \mathrm{~m}$ in other areas (Badcock, 1970; Clarke, 1973; Badcock and Merrett, 1976; Karnella and Gibbs, 1977), which is deeper than my day tows. Trawl avoidance is unlikely to be a major cause of reduced day catches for these small fishes because of the large sampling area of the Engel midwater trawl.

\section{Sampling Limitations}

My conclusions are limited by the sampling strategy. The limitations are:

(1) Small sample size is, perhaps, the most serious shortcoming of the sampling program. Patchy distributions, stray catches and variations in trawl performance can lead to erroneous conclusions when only 1-3 samples are taken per stratum. However, the consistent distributional patterns both within and among species argue that the sampling was generally representative.

(2) Midwater trawling gear biases the type and size of species captured (Harrison, 1967). The Engel midwater trawl probably missed the small species and size classes because of escapement through the large meshes near the mouth and the $10 \mathrm{~mm}$ mesh cod lining.

(3) The open trawl increased variability since samples were contaminated by fishes caught at shallower depths during setting and retrieval. Catches of Ceratoscopelus warmingii and Scopelopsis multipunctatus at depths greater than $50 \mathrm{~m}$ outside the eddy were of the same magnitude as might be expected from near surface contamination.

(4) The sampling program was limited to a 2 week period and biological structure of eddies can change seasonally (Tranter et al., 1980 a) or with eddy age (Wiebe et al., 1976).

(5) Positions with respect to the eddy were defined by temperature at $250 \mathrm{~m}$, which may not exactly correspond to those water masses directly affected by eddy dynamics.

(6) Vertical migrations of fishes throughout the night may have affected results since trawl samples were not standardized at time intervals shorter than $10 \mathrm{~h}$.

\section{Physical and Biological Factors}

The mechanism creating and maintaining the contrasts in the fish communities cannot be determined with my data. The eddy community was probably originally established during eddy formation when a group of organisms was trapped within the eddy and trans- ported with it. This process is similar to that proposed for the euphausid community associated with coldcore rings of the Gulf Stream (Wiebe et al., 1976).

This biological system has probably changed during the eddy's 7-10 months' existence. Whether the eddy remains ecologically distinct from surrounding water masses is not known. Scattered catches of some species throughout all regions suggest that the eddy is not $100 \%$ effective as a barrier (see discussion by Brandt and Wadley, in press). Fish migrations into and out of the eddy would dilute any original differences in species assemblages. Perhaps the eddy has not been in existence long enough for species to mix completely although a mean speed of only $3.5 \mathrm{~mm} \mathrm{~s}^{-1}$ (300 $\mathrm{m} \mathrm{d}^{-1}$ ) would be sufficient to traverse an eddy radius for a $200 \mathrm{~d}$ old eddy. Emigrating species would tend to be lost to surrounding water masses.

Fish could also be advected into the eddy when water from the East Australian Current is entrained along the eddy perimeter (Tranter et al., 1980 a; Brandt et al., 1981; Nilsson and Cresswell, 1981). These intrusions were unlikely during the few months before this study because the East Australian Current was over $600 \mathrm{~km}$ north of Eddy F (Tranter et al., 1980 a). The degree to which migrations and advection are important is probably species and size dependent.

Habitat selection by fishes could maintain or even reinforce the differences in species assemblages. Differences in habitat preferences among species would isolate the eddy community from the surrounding water masses because of the sharp environmental gradients at the eddy edge. Both physical-chemical (temperature, salinity, turbidity, water velocity, oxygen, nutrients) and biological (phytoplankton productivity, prey availability, predator intensity, competitors) factors could be important. For example, distributions of some of the species in this study corresponded closely to temperature, and behavioural thermoregulation of fish has been well documented (Ferguson, 1958; Hela and Laevastu, 1970; Brett, 1971; Fry, 1971; Neill and Magnuson, 1974; Wylie et al., 1976; Coutant, 1977; Magnuson and Beitinger, 1978). Vertically migrating species would also experience a different (higher) total heat budget inside than outside the eddy (Griffiths and Brandt, unpubl.).

Biological interactions could be important. The abundances of potential prey, predators and competitors may differ inside and outside the eddy and responses of fishes to these factors could help maintain the differences in species assemblages between the two regions. For example, Tranter et al., (1980 a) have documented a time lag of 1-2 months between the development of a phytoplankton bloom inside Eddy $F$ and in surrounding water masses. In September 1978 phytoplankton levels were much higher outside Eddy 
F than inside; by November the situation had reversed. These differences in phytoplankton productivity could in turn affect prey availability. Indeed, individuals of Scopelopsis multipunctatus and Ceratoscopus warmingii did differ in diet inside and outside the eddy. Perhaps the apparent growth differences between individuals of the same species occurring inside and outside the eddy may have been caused by differences in both thermal environment and diet.

Extending this argument further, if species inhabit and forage in different thermal zones or water masses, potential predator-prey and competitive interactions could also be minimized (MacLean and Magnuson, 1977). Since most myctophid species are morphologically (functionally) similar, one might expect such fine-scale resource partitioning among and within species (Schoener, 1974; MacLean and Magnuson, 1977; Magnuson et al., 1979; Brandt, 1980; Brandt et al, 1980). For example the closely related species Lobianchia gemellarii and $L$. dofleini appeared to be segregated by temperature and there is evidence that size classes of Diaphus termophilus were occupying different thermal zones. These potential secondary effects of eddies need to be examined further

My data suggest that warm-core eddies play an important, yet relatively unknown role in the biological processes of western boundary regions. In the Tasman Sea these eddies may exist for at least 18 months (Nilsson and Cresswell, in press) and at times are more productive than surrounding water masses. Whether fishes within the eddy are thriving or are expatriates (Zurbrigg and Scott, 1972) is not known. Since about two thirds of the eddies re-coalesce with the East Australian Current (Nilsson and Cresswell, 1981) the eddy community may be reintroduced into the main current system. A time-series study of one or more eddies is needed to assess the impact of eddies on the pelagic community as a whole.

Acknowledgements. I thank the crew and scientific staff of the FRV Courageous for help at sea. Drs John Paxton and David Tranter provided many useful suggestions on the manuscript. H. Lucy Hodgson identified the myctophids.

\section{LITERATURE CITED}

Andrews, J. C., Scully-Power, P. (1976). The structure of an East Australian Current anticyclonic eddy. J. phys. Oceanogr 6: 756-765

Backus, R. H., Craddock, J. E. (1977). Pelagic faunal provinces and sound scattering levels in the Atlantic Ocean. In: Andersen, N. R., Zahuranec, B. J. (eds) Oceanic sound scattering prediction. Marine science, Vol. 5. Plenum Press, New York, pp. 529-547

Backus, R. H., Craddock, J. E., Haedrich, R. L., Robinson, B. H. (1977). Atlantic mesopelagic zoogeography. Fishes of the western North Atlantic. Mem. Sears Fdn mar Res. No. 1, Part 6: 266-287
Backus, R. H., Craddock, J. E., Haedrich, R. L., Shores, D. L. (1969). Mesopelagic fishos and thermal fronts in the western Sargasso Sea. Mar Biol. 3: 87-106

Backus, R. H., Craddock, J. E., Haedrıch, R. L., Shores, D. L. (1970). The distribution of mesopclagic fishes in the equatorial and western North Atlantic. J. mar Res. 28: $179-201$

Badcock, J. (1970). The vertical distribution of mesopelagic fishes collected on the SOND Cruse. J. mar bıol. Ass. U.K. 50: 1001-1044

Badcock, J., Merrett, N. R. (1976). Midwater fishes in the eastern North Atlantic. I. Vertical distribution and associated biology in $30^{\circ} \mathrm{N}, 23^{\circ} \mathrm{W}$, with developmental notes on certain myctophids. Prog. Oceanogr $7: 3-58$

Baird, R. C. (1971). The systematics, distribution and zoogeography of the marine hatchet fishes (Family Sternoptychidae). Bull. Mus. comp. Zool. Harv. 142: 1-128

Becker, $V$ E. (1964). On the temperate - cold water complex of myctophids (Myctophidae, Pisces). Okeanologiya 4: 469-475. Engl. transl. U.S. National Museum Translation No. 62 and National Center for Systematics, Bureau of Commercial Fisheries Translation No. 65

Bigelow, H. B., Cohen, D. M., Dick, M. M., Gibbs, R. H. Jr., Grey, M., Morrow, J. E. Jr., Schultz, L. P., Walters, V (1964). Fishes of the western North Atlantic. Mem. Sears Fdn mar Res. No. 1, Part 4: 1-599

Boland, F. M. (1973). A monitoring section across the East Australian Current. Tech. Pap. Div. Fish. Oceanogr CSIRO Aust. $34: 1-9$

Brandt, S. B. (1980). Spatial segregation of adult and youngof-the-year alewives across a thermocline in Lake Michigan. Trans. Am. Fish. Soc. 109: 469-478

Brandt, S. B., Magnuson, J. J., Crowder, L. B. (1980). Therma! habitat partitioning by fishes in Lake Michigan. Can. J. Fish. Aquat. Sci. 37: 1557-1564

Brandt, S. B., Parker, R. R., Vaudrey, D. (1981). Physical and biological description of warm-core eddy J during September-October, 1978. Rep. Div. Fish. Oceanogr C.S.I.R.O. Aust. 126: 1-52

Brandt, S. B., Wadley, V A. (in press). Thermal fronts as ecotones and zoogeographic barriers in marine and freshwater systems. Proc. Ecol. Soc. Aust. 11

Brett, J. R. (1971). Energetic responses of salmon to temperature. A study of some thermal relations in the physiology and freshwater ecology of sockeye salmon (Oncorhynchus nerka). Am. Zool. 11: 99-113

Clarke, T A. (1973). Some aspects of the ecology of lantern fishes (Myctophidae) in the Pacific Ocean near Hawaii. Fish. Bull. Fish Wildl. Serv. U.S. 71: 401-434

Coutant, C. C. (1977). Compilation of temperature preference data. J. Fish. Res. Bd Can. 34: 739-745

Ebeling, A. W. (1962). Melamphaidae. I. Systematics and zoogeography of the species in the bathypelagic fish genus Melamphaes Günther Dana Rep. 58: 1-164

Ekman, S. (1953). Zoogeography of the sea, Sidgwick and Jackson, London

Fasham, M. J. R., Foxton, P. (1979). Zonal distribution of pelagic decapoda (Crustacea) in the eastern North Atlantic and its relation to the physical oceanography. J. exp. mar. Biol. Ecol. 37: 225-253

Ferguson, R. G. (1958). The preferred temperatures of fish and their midsummer distribution in temperate lakes and streams. J. Fish. Res. Bd Can. 15: 607-624

Foxton, P. (1972). Observations on the vertical distribution of the genus Acanthephyra (Crustacea, Decapoda) in the eastern North Atlantic, with particular reference to the 'purpurea' group. Proc. R. Soc. Edinb. (Sect. B) 73: 301-313 
Fry, F. E. J. (1971). The effect of environmental factors on the physiology of fish. In: Hoar, W. S., Randall, D. J. (eds.) Fish physiology, Vol. 6, Environmental relations and behavior Academic Press, New York, pp. 1-98

Fuglister, F. C. (1972). Cyclonic rings formed by the Gulf Stream 1965-66. In: Gordon, A. (ed.) Studies in physical oceanography. Gordon and Breach, New York, pp. $137-168$

Greenwood, P. H., Rosen, D. E., Weitzmann, S. H., Myers, G. S. (1966). Phyletic studies of teleostean fishes, with a provisional classification of living forms. Bull. Am. Mus nat. Hist. 134: 1-455

Hamon, B. V. (1965). The East Australian current, 1960-1964. Deep Sea Res. 12: 899-921

Harrison, C. M. H. (1967). On methods of sampling mesopelagic fishes. Symp. Zool. Soc. Lond. 19: 71-126

Hela, I., Laevastu, T. (1970). Fisheries oceanography, Fishing News Books, London

Hutchins, L. W. (1947). The bases for temperature zonation in geographic distribution. Ecol. Monogr. 17: 325-335

Jahn, A. E., Backus, R. H. (1976). On the mesopelagic fish faunas of the Slope Water, Gulf Stream, and rorthern Sargasso Sea. Deep Sea Res. 23: 223-234

Jeffrey, S. W., Hallegraeff, G. M. (1980). Studies of phytoplankton species and photosynthetic pigments in a warm core eddy of the East Australian Current. I. Summer populations. Mar. Ecol. Prog. Ser. 3: 285-294

Karnella, C., Gibbs, R. H. (1977). The lantern fish Lobianchia dofleini: an example of the importance of life-history information in prediction of oceanic sound scattering. In: Andersen, N. R., Zahnranec, B. J. (eds.) Oceanic sound scattering prediction. Plenum Press, New York, pp. 361-379

MacLean, J., Magnuson, J. J. (1977). Species interactions in percid communities. J. Fish. Res. Bd Can. 34: 1941-1951

Magnuson, J. J., Beitinger, T L. (1978). Stability of temperatures preferred by centrarchid fishes and terrestrial reptiles. In: Reese, E. (ed.) Contrasts in behavior Wiley, London, pp. 181-216

Magnuson, J. J., Brandt, S. B., Stewart, D. J. (in press). Habitat preferences and fishery oceanography. In: Bardach, J. E., Magnuson, J. J., May, R. C., Reinhart, J. M. (eds.) Fish behavior and its use in the capture and culture of fishes. International Center for Living Aquatic Resources Management, Manila, pp. 371-382

Magnuson, J. J., Crowder, L. B., Medvick, P. A. (1979). Temperature as an ecological resource. Am. Zool. 19: 331-343

McGowan, J. A. (1971). Ocean biogeography of the Pacific. In: Funnel, B. M. Riedel, W. R. (eds) The micropaleontology of the oceans. Cambridge University Press, Cambridge, pp. 3-74

McGowan, J. A. (1974). The nature of oceanic ecosystems. In: Miller, C. B. (ed.) The biology of oceanic Pacific. Oregon State University, Corvallis, pp. 9-28

Nafpaktitis, B. G. (1975). Review of the lantern fish genus Notoscopelus (Family Myctophidae) in the North Atlantic and the Mediterranean. Bull. mar. Sci. Gulf Caribb. 25: $75-87$

Nafpaktitis, B. G. (1978). Systematics and distribution of lantern fishes of the genera Lobianchia and Diaphus (Myctophidae) in the Indian Ocean. Bull. Los Ang. Mus nat. Hist. Sci. 30: 1-92

Nafpaktitis, B. G., Backus, R. H., Craddock, J. E., Haedrich, R. L., Robinson, B. H., Karnella, C. (1977). Family Myctophidae. In: Fishes of the Western North Atlantic. Mem. Sears Fdn mar. Res. No. 1, Part 6: 13-265

Nafpaktitis, B. G., Nafpaktitis, M. (1969). Lantern fishes (Fam- ily Myctophidae) collected during cruises 3 and 6 of the $\mathrm{R} / \mathrm{V}$ Anton Bruun in the Indian Ocean. Bull. Los A.ng. Mus. nat. Hist. Sc1. 5: 1-79

Neill, W H., Magnuson, J. J. (1974). Distributional ecology and behavioral thermoregulation of fishes in relation to heated effluent from a power plant at Lake Monona, Wisconsin. Trans. Am. Fish. Soc. 103: 663-710

Nilsson, C. S. (1977). Measurement of surface currents around an eddy (U). Royal Australian Navy Research Laboratory Tech. Note 5/77: 1-17

Nilsson, C. S., Andrews, J. C., Scully-Power, P. (1977). Observations of eddy formation off east Australia. I phys. Oceanogr 7: 659-669

Nilsson, C. S., Cresswell, G. R. (1981). The formation and evolution of East Australian Current eddies. Progr Oceanogr. 9: 133-183

Odum, E. P. (1971). Fundamental of ecology, W. B. Saunders, Philadelphia

Ortner, P. B., Hulburt, E. M., Wiebe, P. H. (1979). Phytohydrography, Gulf Stream rings, and herbivore habitat contrasts. J. exp. mar. Biol. Ecol. 39: 101-124

Parker, C. E. (1971). Gulf Stroam rings in the Sargasso Sea. Deep Sea Res. 18: 981-993

Rass, T S. (1960). Geographic distribution of bathypelagic fishes of the family Myctophidae in the Pacific Ocean. Trudy Inst. Okeanol. Adad. Nauk SSSR 41: 146-152. Translation issued by the Ichthyological Laboratory, U.S. Bureau of Commercial Fishes, Washington

Robertson, D. A., Roberts, P. E., Wilson, J. B. (1979). Mesopelagic faunal transition across the subtropical convergence east of New Zealand. N.Z. Jl mar. Freshwat. Res. 12: $295-312$

Schoener, T W (1974). Resource partitioning in ecological communities. Science, N.Y 185: 27-39

Scott, B. D. (1978). Hydrological features of a warm core-eddy and their biological implications. Rep. Div. Fish. Oceanogr C.S.I.R.O. Aust. 100: 1-18

Terborgh, J. (1971). Distribution on environmental gradients: theory and a preliminary interpretation of distributional patterns in the avifauna of the Cordillera Vilcabamba, Peru. Ecology 52: 23-40

Tomosada, A. (1978). A large warm eddy detached from the Kuroshio east of Japan. Bull. Tokai. reg. Fish. Res. Lab. 94: 59-103

Tranter, D. J., Parker, R. R., Cresswell, G. R. (1980 a). Are warm-core eddies unproductive? Nature, Lond. 284 : $540-542$

Tranter, D. J., Parker, R. R., Vaudrey, D. J. (1980 b). In vivo chlorophyll a fluorescence in the vicinity of warm-core eddies off the coast of New South Wales. 4. December 1978. Rep. Div. Fish. Oceanogr. C.S.I.R.O. Aust. 113: 1-32

Tranter, D. J., Parker, R. R., Gardner, D., Campbell, R. $(1980 \mathrm{c})$. In vivo chlorophyll a fluorescence in the vicinity of warm-core eddies off the coast of New South Wales 3 November 1978. Rep. Div. Fish. Oceanogr C.S.I.R.O. Aust. 112: 1-27

Wiebe, P. H. (1976). The biology of cold-core rings. Oceanus 19: $69-76$

Wiebe, P. H., Boyd, S. H. (1978). Limits of Nematoscelis megalops in the northwestern Atlantic in relation to Gulf Stream cold core rings. Part I. Horizontal and vertical distributions. J. mar. Res. 36: 119-142

Wiebe, P. H., Hulburt, E. M., Carpenter, E. J., Jahn, A. E., Knapp, G. P., Boyd, S. H., Ortner, P. B., Cox, J. L. (1976). Gulf Stream cold core rings: Large-scale interaction sites for open ocean plankton communities. Deep Sea Res. 23: 695-710 
Wisner, R. L. (1976). The taxonomy and distribution of lantern fishes (Family Myctophidae) of the Eastern Pacific Ocean. Mississippi, Navy Ocean Research and Development Acitivity. NORDA Rep. 3: 1-299

Wyllie, M. C., Holmstrom, E. R., Wallace, R. K. (1976). Temperature preference, avoidance, shock, and swim speed studies with marine estuarine organisms from New Jersey Ichthyological Associates, Inc., Brigantine, N.J. Bull. No. 15: $1-76$

Zurbrigg, R. E., Scott, W B. (1972). Evidence for exputriate populations of the lantern fish Myctophum punctatum in the northwest Allantic J. Fish. Re's. Bd Can. 29: 1679-1683

This paper was presented by Dr G. F. Humphrey; it was accepted for printing on April 25, 1981 